6. Trân Văn Ngọc. (2011). Các yếu tố nguy cơ tử vong của đợt cấp copd. Tạp chí y học thành phố Hồ Chí Minh, 15: 8.

7. Nguyễn Hải Công, Tạ Bá Thắng, Nguyễn Huy Lức. (2021). Study on prognostic values for mortality of clinical and subclinical factors in acute exacerbation of chronic obstructive pulmonary disease. Journal of Military Pharmaco - Medicine, 2: 7.

8. Trân Văn Đồng, Nguyển Văn Chi, Nguyễn
Ngoc Sơn. (2017). So sánh giá trị dự đoán sự cân thiết phải thông khí nhân tạo của bảng điểm BAP65 và CURB-65 ở bênh nhân đợt cấp bênh phổi tắc nghẽn man tính. Tạp chí y dược học, trường đại hoc y Huế, 7: 60-63.

9. Yousif M., El Wahsh R.A. (2016). Predicting inhospital mortality in acute exacerbation of COPD: Is there a golden score? Egyptian Journal of Chest Diseases and Tuberculosis, 65(3): 579-584.

\title{
ĐÁNH GIÁ KẾT QUẢ ĐIỀU TRI TRĨ VÒNG HỖN HỢP Độ IV BẰNG PHẪU THUẬT WHITEHEAD TẠI BỆNH VIỆN TRUNG ƯƠ'NG QUÂN ĐộI 108
}

Diêm Đăng Bình, Triệu Triều Dương, Hồ Hữu An, nguyễn Văn Trưởng, Vũ Ngọc Sơn, Phạm Thị Huế, Ngố Thị To, Trần Thị Hà

\section{TÓM TẮT}

Phẫu thuật Whitehead được xem là phương pháp phù hợp trong điều trị trĩ vòng hỗn hợp độ IV, tuy nhiên tỳ lệ tai biến, biến chứng còn cao. Ngày nay, với sự phát triển của các dụng cụ cầm máu giúp hạn chế được nhược điểm của phẩu thuật Whitehead. Nghiên cứu được thực hiện với mục tiểu: Đánh giá kết quả điều trị trĩ vòng hỗn hợp độ IV bằng phẫu thuật Whitehead tai Bệnh viên TWQ்Đ108. Đối tượng và phương pháp nghiện cứu: Nghiên cứu mô tả tiến cứu $55 \mathrm{BN}$ trĩ vòng hỗn hợp độ IV được điều trị bằng phẩu thuât Whitehead tai Bênh viên TWQĐ 108. Kêt quả: $72,7 \%$ bệnh nhân nam, tuổi trung bình 52,6 tuổi. $61,8 \%$ bệnh nhân được phấu thuật whitehead có sử dụng dao Ligasure và $38,2 \%$ sử dụng chày tự chế. Lượng máu mất, thời gian phẫu thuật và đau sau mổ của nhóm sử dụng Ligasure ngắn hớn so với dùng chày $(\mathrm{p}<0,05)$. Biến chứng sớm $27,3 \%$. Thời gian theo dõi xa trung bình 15,4 tháng, biến chứng xa $7,3 \%$, không bệnh nhân nào tái phát. $98,8 \%$ tự chủ hậu môn hoàn toàn tại thời điểm kết thúc nghiên cứu. Kểt luận: Cắt trĩ theo Whitehead là phương pháp hiệu quả trong điều trị trĩ vòng hỗn hợp độ IV. Việc áp dụng phương pháp cắt trĩ theo Whitehead với các dựng cự hố trợ hoặc phương tiên cầm máu tùy thuộc vào thói quen của phẩu thuật viên.

Tư khóa: Trĩ vòng, Whitehead

\section{SUMMARY}

\section{RESLTS OF TREATMENT OF GRADE IV HEMORRHOIDS BY WHITEHEAD'S HEMORRHOIDECTOMY}

Whitehead surgery is considered a suitable method to treat grade IV mixed-ring hemorrhoids, but the rate of complications is still high. Nowadays, the

*Bênh viên Trung ương Quân đôi 108

Chịu trách nhiệm chính: Diêm Đăng Bình

Email: drbinhbv108@gmail.com

Ngày nhận bài: 9.9.2021

Ngày phàn biên khoa họ: 26.10.2021

Ngày duyệt bài: 10.11.2021 development of vessel sealing devices helps to limit the disadvantages of Whitehead surgery. The study was carried out with the objective: To evaluate the results of treatment of grade IV mixed ring hemorrhoids by Whitehead surgery at 108 Central Military Hospital. Subjects and methods: Prospective descriptive study of 55 patients with grade IV mixed ring hemorrhoids treated by Whitehead surgery using Ligasure or pestle at the Department of Anal - Rectal and Pelvic Floor - 108 Central Military Hospital Results: The average age of patients was 52.6 years old, males accounted for $72.7 \%$. The mean duration of illness was 83.4 months. 34 patients $(61.8 \%)$ underwent whitehead surgery using a Ligasure vessel sealing device and 21 patients $(38.2 \%)$ used a homemade pestle. The amount of blood loss, surgery time, and postoperative pain of the group using Ligasure was shorter than that of using the pestle $(p<0.05)$. Early complications $27.3 \%$. The average follow-up time was 15.4 months, late complications were $7.3 \%$, no recurrence. $98.8 \%$ had complete anal autonomy at the end of the study. Conclusion: Whitehead's hemorrhoidectomy is an effective method in the treatment of grade IV mixed ring hemorrhoids with a low rate of complications and recurrence. The application of Whitehead's hemorrhoidectomy with supporting instruments or vessel sealing devices depends on the surgeon's habits.

\section{I. ĐẶT VẤN ĐỀ}

Trĩ là tình trạng bệnh lý thường gặp trên lâm sàng và xảy ra ở mọi lứa tuổi, trong đó tỷ lệ mắc bệnh ở nhóm trên 40 tuổi vào khoảng 58\% [7]. Trĩ vòng hỗn hợp độ IV là một trong những tổn thương trĩ phức tạp, chiếm hết chu vi ống hậu môn, do vậy vẫn còn nhiều tranh luận về lựa chọn kĩ thuật cắt trĩ thực sự hiệu quả đối với trĩ những trường hợp này [6]. Năm 1882, Whitehead W. lần đầu mô tả kỹ thuật cắt bỏ toàn bộ trĩ vòng với một đường rạch ở niêm mạc, sau đó phẫu tích lớp niêm mạc kèm những 
búi trĩ; khi phẫu tích đến vùng phía trên búi trĩ, cắt ngang niêm mạc và lấy bỏ vòng niêm mạc trĩ, diện cắt niêm mạc phía trên được khâu với diện cắt da ở phía dưới [8]. Từ đó, các tác giả cho rằng phẫu thuật cắt trĩ theo Whitehead vẫn được xem là phương pháp phù hợp và triệt để nhất trong các trường hợp trĩ vòng hỗn hợp độ IV[1], [3]. Tuy nhiên, đây vẫn được xem là phẫu thuật "tàn phá" vùng hậu môn trực tràng do mất máu trong mổ nhiều và tỷ lệ biến chứng sau mổ còn cao, bao gồm hẹp hậu môn $(8,8 \%)$, mất tự chủ $(2-12 \%)$, bí tiểu (2-50\%) và đau nhiều sao mổ (> 50\%). [2], [3], [7]. Ngày nay, những tiến bộ trong phát triển dụng cụ phấu thuật gần đây đã dẫn đến sự ra đời của các thiết bị nhiệt điện lưỡng cực - dao mổ siêu âm, dao hàn mạch ligasure với khả năng cầm máu cao và các dụng cụ cải biên, cho phép thực hiện các phẫu thuật cắt trĩ một cách đơn giản và hiệu quả hơn, đặc biệt là phẫu thuật Whitehead. Mục tiêu nghiển cứu nhằm: Đánh giá kết quả điều trị trĩ hốn hợp độ IV bằng phẫu thuật Whitehead tại Bệnh viên TWQD108.

\section{II. ĐỐI TƯƠNG VÀ PHƯƠ'NG PHÁP NGHIÊN CỨU}

2.1. Đối tượng: Gồm 55 BN được chẩn đoán trĩ vòng hỗn hợp độ IV và được điều trị bằng phẫu thuật Whitehead tại Khoa Hậu môn - Trực tràng và Sàn chậu - Bệnh viện TWQĐ 108 từ tháng 8/2018 đến tháng 4/2021, theo dõi xa đến tháng $8 / 2021$

2.2. Phương pháp: Nghiên cứu mô tả tiến cứu, có theo dõi dọc.

Mô tả kỹ thuật

- Kỹ thuật Whitehead kinh điển kết hợp với dao hàn mạch Ligasure

+ Dùng panh kẹp 4 góc tại các búi trĩ lớn, dùng dao điện rạch, tách phần chuyển tiếp giữa da - niêm mạc ống hậu môn và cơ thắt ra khỏi búi trĩ.

+ Dùng Ligasure cắt toàn bộ búi trĩ và khoanh niêm mạc ống hậu môn đển phần niêm mạc trực tràng lành phía trên đường lược. Khâu niểm mạc trực tràng với da ống hậu môn bằng chỉ Vicryl $3 / 0$ mũi rời. Nong hậu môn và băng ép gạc Betadine. tự chế

- Kỹ thuật Whitehead sử dụng dụng cụ "chày"

+ Dùng chỉ lanh khâu tại 6 điểm gốc mạch các búi trĩ phía trên đường lược. Đưa dụng cụ "chày" vào hậu môn, buộc 6 mối chỉ với 6 "ngạnh" của chày, kéo căng ra để toàn bộ các búi trĩ và niêm mạc ống hậu môn và đường lược được kéo ra ngoài.
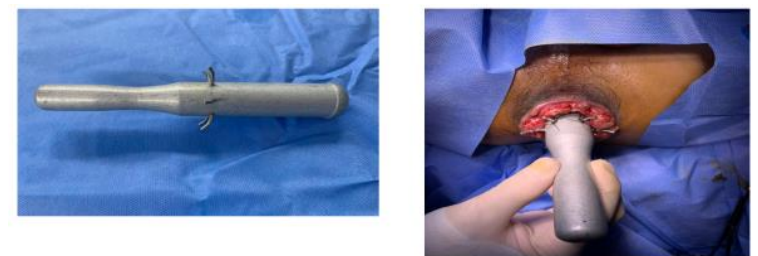

Hình 1. Dụng cụ chày tự chế

+ Dùng vòng cao su cổ găng buộc garo toàn bộ vòng trĩ theo vòng của chày.
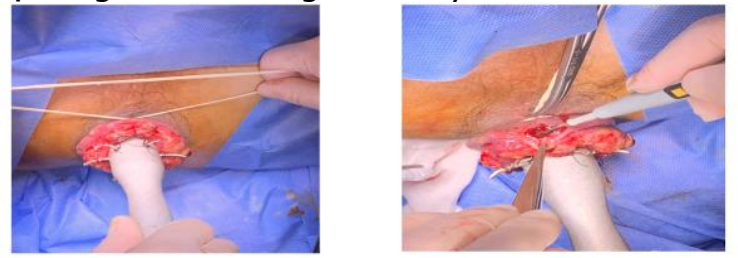

Hình 2. Garo và cắt toàn bộ trĩ vòng

+ Sử dụng dao điện cắt bỏ toàn bộ khoanh trĩ vòng kèm da, niêm mạc ống hậu môn phía trước đường garo, đồng thời khâu niểm mạc trực tràng còn lại với da ống hậu môn bằng chỉ Vicryl $3 / 0$ mũi rời. Sau khi khẩu đủ vòng trĩ, tháo garo, kiểm tra, có thể khâu cầm máu bổ sung.
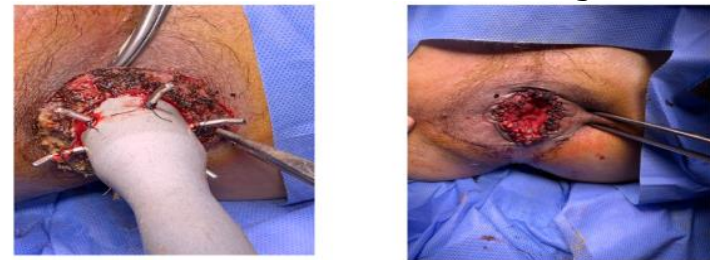

Hình 3. Khâu niêm mạc trực tràng với da ống hậu môn

Các chỉ tiêu nghiên cứu

- Đặc điểm chung: Tuổi, giới, thời gian mắc bệnh, phương pháp điều trị trước đó.

- Đặc điểm phẫu thuâât

+ Phương pháp phẩu thuật: Whitehead với Ligasure/ whitehead với "chày"

+ Lượng máu mất trong mổ, thời gian phẫu thuât

- Kêt quả sớm (xảy ra trong vòng 1 tháng sau mổ):

+ Biến chứng sớm (chảy máu, bí tiểu, nhiễm khuẩn vết mổ, bục đường khâu niêm mạc trực tràng $-\mathrm{da}, \ldots$ )

+ Thời gian đau, thời gian nằm viện sau mổ.

- Kết quả tính tới thời điểm kết thúc nghiên cứu (tháng 8/2021):

+ Thời gian theo dõi xa

+ Biến chứng xa:

Mất tự chủ hậu môn (đánh giá theo bảng phân độ của Wexner)

Hẹp hậu môn đánh giá theo phân độ của Milsom và Mazier: hẹp nhẹ (có thể đút vừa 2 ngón tay), hẹp vừa (đút vừa 1 ngón tay) và hẹp nặng (không thể thăm hậu môn bằng ngón tay 
hoặc ống soi mềm $1 \mathrm{~cm}$ ) -> điều trị bằng nong hậu môn/ phẫu thuật.

Biến chứng khác: Rỉ dịch từ hậu môn, nứt kẽ hậu môn,...

\section{KẾT QUẢ NGHIÊN CỨU}

Bảng 1. Đặc điểm chung

\begin{tabular}{|c|c|}
\hline Chỉ tiêu đánh giá & Kết quả \\
\hline Tuổi & $52,6 \pm 15,4$ tuối \\
& $(21-80$ tuổi $)$ \\
\hline Giới & Nam: $40(72,7 \%)$ \\
& Nữ: $15(27,3 \%)$ \\
\hline
\end{tabular}

\begin{tabular}{|c|c|c|c|}
\hline \multicolumn{2}{|c|}{ Thời gian mắc bệnh } & \multicolumn{2}{|c|}{$\begin{array}{c}83,4 \pm 78,6 \text { tháng } \\
(5-360 \text { tháng) }\end{array}$} \\
\hline \multicolumn{4}{|c|}{ Bảng 2. Đặc điếm phấu thuật } \\
\hline \multirow[b]{2}{*}{$\begin{array}{l}\text { Chỉ tiêu } \\
\text { đánh giá }\end{array}$} & \multicolumn{2}{|c|}{ Phương pháp phâu thuật } & \multirow[b]{2}{*}{$\mathrm{p}$} \\
\hline & $\begin{array}{c}\text { Whitehead } \\
\text { dùng Ligasure }\end{array}$ & $\begin{array}{l}\text { Whitehead } \\
\text { dùng chày }\end{array}$ & \\
\hline $\begin{array}{l}\text { Số BN } \\
(n=55)\end{array}$ & $34(61,8 \%)$ & $21(38,2 \%)$ & \\
\hline $\begin{array}{l}\text { Lượng máu } \\
\text { mất }\end{array}$ & $15,3 \pm 5,6 \mathrm{ml}$ & $30,4 \pm 6,8 \mathrm{ml}$ & $<0,05$ \\
\hline $\begin{array}{c}\text { Thời gian } \\
\text { phẫu thuật }\end{array}$ & $\begin{array}{l}40,1 \pm 14,5 \\
\text { phút }\end{array}$ & $\begin{array}{l}56,5 \pm 10,2 \\
\text { phút }\end{array}$ & $<0,05$ \\
\hline
\end{tabular}

Bảng 3. Kêt quả điều trị

\begin{tabular}{|c|c|c|c|}
\hline \multirow[b]{2}{*}{$\begin{array}{l}\text { Chỉ tiêu } \\
\text { đánh giá }\end{array}$} & \multicolumn{2}{|c|}{$\begin{array}{l}\text { Phương pháp phâu thuật } \\
\end{array}$} & \multirow[b]{2}{*}{ P } \\
\hline & $\begin{array}{l}\text { Whitehead dùng } \\
\text { Ligasure }(\mathrm{n}=\mathbf{3 4})\end{array}$ & $\begin{array}{l}\text { Whitehead dùng chày } \\
\qquad(\mathrm{n}=21)\end{array}$ & \\
\hline Thời gian đau & $2,0 \pm 0,9$ ngày & $2,7 \pm 1,3$ ngày & $<0,05$ \\
\hline Biến chứng sớm & $9 / 34(26,5 \%)$ & $6 / 21(28,6 \%)$ & 0,44 \\
\hline Biến chứng cụ thể & Bí tiểu: 9 (26,5\%) & $\begin{array}{l}\text { Bí tiếu: } 5(23,8 \%) \\
\text { Cháy máu: } 1(4,8 \%)\end{array}$ & \\
\hline Thời gian nằm viện sau mố & $4,79 \pm 1,4$ ngày & $5,24 \pm 1,5$ ngày & 0,27 \\
\hline Biến chứng xa & $3 / 34(8,8 \%)$ & $1 / 21(4,8 \%)$ & $>0,05$ \\
\hline Biến chứng xa cụ thế & Hẹp hậu môn vừa: 8,8\% & Mất tự chủ độ 2: 4,8\% & \\
\hline Tái phát & \multicolumn{2}{|c|}{$0 \%$} & - \\
\hline $\begin{array}{l}\text { Chức năng tự chủ hậu môn tai } \\
\text { thời điểm kết thúc nghiên cứu }\end{array}$ & \multicolumn{2}{|c|}{$98,8 \%$ tự chủ hoàn toàn } & \\
\hline
\end{tabular}

- Nhận xét: + Biến chứng sớm chung là $27,3 \%$, chủ yếu là bí tiểu $25,5 \%$

+ Thời gian theo dõi xa trung bình 15,4 \pm 12,3 tháng (4 - 36 tháng)

+ Biến chứng xa chung là 7,3\%. Tái phát $0 \%$

+ 54/55 BN 98,8\% tự chủ hậu môn hoàn toàn tại thời điểm kết thúc nghiên cứu

\section{BÀN LUẬN}

Theo phân loại tổn thương, trĩ được chia làm: trĩ nội (búi trĩ xuất phát từ trên đường lược), trĩ ngoại (búi trĩ xuất phát từ dưới đường lược) và trĩ hỗn hợp (bao gồm cả trĩ nội cà trĩ ngoại). Ngoài ra, theo kích thước và biễn biến lâm sàng, trĩ được phân thành 4 độ: I, II, III, IV. Trong đó, trĩ vòng hỗn hợp độ IV luôn được xem là thể trĩ phức tạp nhất do búi trĩ lớn, chiếm hết toàn bộ chu vi ống hậu môn và phá vỡ cấu trúc cầu da niêm mạc, gẩy khó khăn cho việc lựa chọn chiến thuật điều trị. Kể từ khi ra đời vào năm 1882, phẫu thuật Whitehead với nguyên tắc cắt bó toàn bộ khoanh niêm mạc ống hậu môn và tổ chức trĩ được cho là phương pháp hiệu quả và triệt để nhất trong điều trị trĩ vòng hổn hợp độ IV [3], [1]. Mặc dù vậy, với độ phức tạp của phẫu thuật, tỷ lệ biển chứng hẹp hậu môn $(8,8 \%)$, mất tự chủ $(2-12 \%)$, bí tiểu $(2-50 \%)$ còn khá cao [7], [3], việc lựa chọn kỹ thuật luôn

được các tác giả cân nhắc rất kỹ lưỡng.

Với mục đích nâng cao hiệu quả phẫu thuật điều trị bệnh lý phức tạp này, cùng với sự phát triển của dụng cụ phẩu thuật, chúng tôi đã nghiên cứu phát triển các kỹ thuật cải biên nhằm hạn chế các nhược điểm của phẫu thuật Whitehead kinh điển. Theo đó, 2 kỹ thuật Whitehead cải biên được chúng tôi áp dụng để đánh giá bao gồm sử dụng dụng cụ "chày" tự chế và kết hợp dao hàn mạch Ligasure để cắt khoanh niêm mạc ống hậu mồn.

Trong 55 BN trĩ vòng hốn hợp độ IV được nghiên cứu được chia thành 2 nhóm: 34 BN $(61,8 \%)$ được phẫu thuật whitehead có sử dụng dao hàn mạch Ligasure và $21 \mathrm{BN}(38,2 \%)$ sử dụng chày tự chế. Việc chỉ định lựa chọn phương pháp hoàn toàn ngẫu nhiên, phụ thuộc vào thói quen của phẫu thuật viên. Hai ứng dụng kỹ thuật nhằm mục đích giúp cầm máu búi trĩ trong mổ tốt hơn, tạo điều kiện thuận lợi khi cắt trĩ vòng và khâu phục hồi da hậu môn với niêm mạc trực tràng, tuy nhiên mỗi kỹ thuật đều có những ưu nhược điểm riêng.

Nghiên cứu thấy sử dụng Ligasure trong mổ giúp vừa cắt, vừa hàn mạch cầm máu tốt hơn, qua đó làm giảm lượng máu mất $(15,3 \pm 5,6 \mathrm{ml}$ so với $30,4 \pm 6,8 \mathrm{ml}$ ở nhóm dùng chày) và thời gian phẫu thuật $(40,1 \pm 14,5$ phút so với $56,5 \pm$ 
10,2 phút ở nhóm dùng chày). Trong khi đó khi sử dụng chày tự chế với nhiều bước kỹ thuật làm kéo dài thời gian, tuy nhiên việc chủ động khâu tai 6 vi trí gốc mach và kéo toàn bô búi trĩ ra ngoài giúp vòng trĩ được cố định trong toàn bộ quá trình cắt, giúp diện cắt đều hơn, đảm bảo lấy bỏ toàn bộ búi trĩ, tránh làm tổn thương cơ vòng hậu môn. Bên cạnh đó, chày nằm trong ống hậu môn có tác dụng nong liên tục, tránh hẹp hậu môn sau mổ. Nghiên cứu của Nguyễn Đắc Thào và cộng sự với kỹ thuật Whitehead cải biên (tạo vạt niêm mạc da hậu môn) trên 17 BN thấy thời gian mổ trung bình à $50,6 \pm 12,9$ phút [1]

Kết quả sớm. Thời gian đau sau mổ ở nhóm sử dụng Ligasure $(2,0 \pm 0,9$ ngày) thấp hơn nhóm sử dụng chày $(2,7 \pm 1,3$ ngày). Chúng tôi ghi nhận tỷ lệ biến chứng sớm chung là 27,3\%, chủ yếu là bí tiểu $25,5 \%$ phải đă̆t và lưu sonde tiểu 24-48 giờ, không có sự khác biệt về tỷ lệ biến chứng và thời gian nằm viện sau mổ giữa hai nhóm. Có 1 BN chảy máu sau mổ (ở nhóm dùng chày) được băng ép cầm máu tại chỗ. Nghiên cứu của Woft và công sự [2] trên $484 \mathrm{BN}$ được phẫu thuật Whitehead, trong đó $22 \%$ có biến chứng bí tiểu, $1,3 \%$ chảy máu, $5 \mathrm{BN}$ phải mổ lại. Kenan $E$. và cộng sự ghi nhận các biến chứng sớm bao gồm chảy máu $(6,12 \%)$, tiểu khó $(2,04 \%)$, bí tiểu $(16,33 \%)$ và són tiểu tạm thời $(2,04 \%)$. Thời gian nằm viện trung bình 6,45 ngày [3].

Kết quả tính đến thời điểm kết thúc nghiên cứu. Tất cả $B N$ của chúng tôi đều được theo dõi và tái khám tại thời điểm kết thúc nghiên cứu, với thời gian theo dõi trung bình $15,4 \pm 12,3$ tháng (4 - 36 tháng), ghi nhận tỷ lệ biến chứng xa chung là $7,3 \%$. Trong đó $3 \mathrm{BN}$ hep hậu môn mức độ vừa ở nhóm sử dung Ligasure, chúng tôi hướng dẫn BN tư nong hâuu môn tại nhà, sau 1-2 tháng kiểm tra lại thấy tình trạng hẹp được cải thiện, không phải can thiệp phẫu thuật.

Các nghiên cứu khác cũng ghi nhận hẹp hậu môn sau mổ cắt toàn bộ vòng trĩ theo Whitehead xảy ra ở khoảng 5-10\% các trường hợp, nguyên nhân được cho là do đường khâu niêm mạc trực tràng-da ống hậu môn bị nhiễm khuẩn, không liền, dẫn đến hình thành sẹo xơ thứ phát [3]. Nghiên cứu của Nguyễn Đắc Thao có $1 \mathrm{BN}$ hẹp hậu môn xuất hiện sau mổ 4 tháng, hẹp vừa và phải nong hậu môn [1]. Tỷ lệ hẹp hậu môn sau mổ cắt trĩ bằng phương pháp Whitehead của một số tác giả trên thế giới: Theo Woft [2]: 2/484 BN $(0,4 \%)$; theo Maria [5] trong thời gian theo dõi 3 năm có $1 / 26$ BN hẹp hậu môn 3 tháng sau mổ phải nong hậu môn. Các tác giả thống nhất điều trị hẹp hậu môn bằng chế độ ăn nhiều chất xơ, thuốc nhuận tràng, nong hậu môn, và cuối cùng là phẫu thuật tạo hình hậu môn [1], [4].

Chúng tôi cho rằng do tình trạng đau nhiêu sau mổ, BN chăm sóc vết thương khó khăn làm tăng tỳ lệ nhiễm khuẩn đường khâu, hình thành sẹo xơ hẹp. Ngoài ra, sau mổ người bệnh thường ăn ít do lo ngại đi ngoài sẽ gây đau, do vậy không hình thành phân qua ống hậu môn cũng làm cho tình trạng hẹp hậu môn sau mổ tăng lên. Vì vậy, bên cạnh kỹ thuật, vấn đề chăm sóc phẫu thuật Whitehead cũng đóng vai trò rất quan trọng giúp làm giảm tỷ lệ hẹp hậu môn sau mổ. Chúng tôi thường khuyến khích $B N$ ăn sớm sau mổ 6-8 giờ, sử dụng phối hợp các phương pháp giảm đau, giúp quá trình ngâm rửa và chăm sóc vết mổ vùng hậu môn của $B N$ dễ dàng hơn. Ngoài ra BN được hẹn theo dõi và tái khám sau 2 tuần, 1 tháng và 2 tháng sau mổ để phát hiện sớm tình trạng hẹp, có thể xử lý bằng nong hậu môn mà khồng phải can thệp phẫu thuật.

Đa số BN trong nghiên cứu của chúng tổi đều gặp phải tình trạng mất tự chủ hậu môn tạm thời với hơi và ướt hậu môn trong vòng 1 - 2 tháng đầu sau mổ, sau tháng thứ 3 , các chức năng đại tiên của các $B N$ trở vè bình thường. Đánh giá lại tai thời điểm kết thúc nghiên cứu 98,8\% BN tự chủ hậu môn hoàn toàn. Phân loại theo thang điểm Wexner, nghiên cứu có 1 BN mất tự chủ hậu môn độ 2 kéo ở nhóm sử dụng chày, BN thỉnh thoảng són ít phân và hơi, chúng tôi hướng dẫn BN thay đổi chế độ ăn và tập bài tập Kegel, tình trạng sau đó được cải thiện, đến thời điểm kết thúc nghiên cứu, BN tự đại tiện tự chủ hoàn toàn.

Chúng tôi có cùng nhận định với các tác giả, tình trạng mất tự chủ hậu môn sau phẫu thuật Whitehead có thể do tổn thương lớp đệm vùng ống hậu môn, ngoài ra quá trình phẩu thuật gây tổn thương cơ thắt trong cũng làm giảm chức năng tự chủ hậu môn sau mổ. Nghiên cứu của Woft có 3/484 BN mất tự chủ mức nhẹ sau phẫu thuật Whitehead [2]. Tác giả Nguyễn Đắc Thao có $2 \mathrm{BN}$ mất tự chủ với hơi kéo dài, $2 \mathrm{BN}$ mất tự chủ với hơi tạm thời sau mổ 3 tháng [1].

Trong phầu thuật điều trị bệnh trĩ, tỷ lệ tái phát sau mổ luôn là tiêu chí quan trọng được các tác giả quan tâm. Kỹ thuât Whitehead là cắt toàn bộ vòng trĩ, do đó tỷ lệ tái phát trĩ trong các nghiên cứu trên thế giới là rất thấp. Nghiên cứu của chúng tôi không ghi nhận trường hợp nào tái phát, tương tự tác giả Woft [2] và Nguyễn Đắc Thao [1] với tỷ lệ tái phát đều là $0 \%$. 


\section{KẾT LUÂN}

Cắt trĩ theo Whitehead là phương pháp hiêu quả trong điều trị trĩ vòng hỗn hợp độ IV với tỷ lệ tai biến, biến chứng và tái phát thấp. Việc áp dụng phương pháp Whitehead với các dụng cụ hố trợ tùy thuộc vào thói quen của phẫu thuật viên.

\section{TÀI LIỆU THAM KHẢO}

1. Nguyễn Đắc Thao và Nguyễn Xuân Hùng, "Cắt trĩ phương pháp Whitehead: Những kĩ thuật cải biên và kết quả điều trị", Tạp chí Y Dược lầm sàng 108, 2019. 14(4), tr. 87-93.

2. Wolff B.G., Culp C.E., "The Whitehead hemorrhoidectomy: An unjustly maligned procedure", Diseases of the Colon \& Rectum, $1998,31(8)$, p. 587-590.
3. Kenan E., et al., "The Whitehead operation procedure: Is it a useful technique?", Turk J Surg, 2017, 33(3), p. 190-194.

4. Brisinda G. et al., "Surgical treatment of anal stenosis", World Journal of Gastroenterology. 15(16), 2009, tr. 1921- 1928.

5. Maria G., et al, "Whitehead's hemorrhoidectomy A useful surgical procedure in selected cases", Tech Coloproctol, 2001, 5, p. 93-96.

6. Mukhashavria G.A., Qarabaki M.A., "Circumferential excisional hemorrhoidectomy for extensive acute thrombosis: A 14-year experience", Diseases of the Colon \& Rectum, 2011, 54(9), p. 1162-1169.

7. Agbo S.P., "Surgical Management of Hemorrhoids", J Surg Tech Case Rep, 2011, 3(2), p. 68-75.

8. Whitehead W. (1882), "The surgical treatment of hemorrhoids", Bristish Medical Journal, 1882, 1, p. $148-150$.

\section{CÔNG NGHÊ SCAFFOLD ỨNG DỤNG TRONG CẤY GHÉP TẾ BÀO GỐC ĐÎ̂̀U TRI CÁC TỔN THƯƠ'NG CƠ XƯO'NG KHỚP}

\section{TÓM TẮT}

Scaffold là chất mang hay còn gọi là giá đõ sinh học, hay giàn giáo sinh học, có vai trò quan trọng trong công nghệ cấy ghép tế bào gốc. Trong bài này chúng tôi xin giới sơ lược về scaffold, chất liệu, câu trúc, các đặc tính của scaffold và cách tạo hình 3D scaffold

Tư khoá: Scaffold; giá đõ sinh học, tế bào gốc

\section{SUMMARY}

SCAFFOLD TECHNOLOGY APPLICATION IN STEM CELL TRANSPLANTATION FOR MUSCULOSKELETAL INJURIES TREATMENT

Scaffold is a carrier or biological scaffold, or biological scaffold, that plays an important role in stem cell transplant technology. In this article, we would like to briefly introduce the scaffold, the materials, the structure, the properties of the scaffold and the 3D modeling of the scaffold.

Keywords: Scaffold; biological scaffold, stem cells

\section{I. ĐẶT VẤN ĐỀ}

Ngày nay, với nhịp độ công việc ngày càng cao đã khiến các bệnh lý về xương khớp, sụn, gân, cơ và dây chằng ngày càng gia tăng, phổ biến nhất có thể kể đến bệnh thoái hóa khớp,

\footnotetext{
${ }^{1}$ Đại Học Y Hà Nôi

${ }^{2}$ Bênh viên HN Viêt Đức

Chịu trách nhiêm chính: Dương Đình Toàn

Email: duongdinhtoan@hmu.edu.com

Ngày nhận bài: 13.9.2021

Ngày phản biên khoa hoc: 29.10.2021

Ngày duyệt bài: 15.11.2021
}

Dương Đình Toàn ${ }^{1}$, Nguyễn Đình Hoà ${ }^{1,2}$

chấn thương xương... Đây đều là những căn bệnh khó chữa và đòi hỏi rất nhiều thời gian cũng như chi phí trị liệu, tuy nhiên với sự có mặt của công nghệ tế bào gốc các căn bệnh vốn được coi là mãn tính này đã có lời giải.

Mục tiêu của công nghệ mô là tái tạo các cấu trúc sinh học, nhằm sửa chữa hay thay thế các mô bị tổn thương. Ba yếu tố cấu thành nên công nghệ mô gồm:

- Đầu tiên, tế bào thích hợp phải hiện diện để tạo ra mô câu trúc.

- Thứ hai, nhân tố phát triển thích hợp và các kích thích biệt hóa cho tế bào phải tồn tại để biến đổi tế bào thành dòng thích hợp.

- Thứ ba, các chất nền làm giàn scaffold (scaffold) hoạt động như là một bệ đõ giúp cho sự bám dính tế bào, sự biệt hóa và sự trưởng thành mô mong muốn. Cấu trúc được tạo ra phải chuyên biệt vị trí và sát nhập tốt tại bề mặt cây ghép của vật chủ.

Như vậy scaffold là một trong 3 yếu tố cấu thành công nghệ tế bào gốc đang được nghiên cứu, ứng dụng hiện nay.

\section{TỔNG QUAN}

2.1 Giàn scaffold sinh học. Scaffold là chất mang hay còn gọi là giá đõ sinh học, hay giàn giáo sinh học, có vai trò quan trọng trong công nghệ cấy ghép tế bào gốc điều trị bệnh lý nói chung và các bệnh lý về cơ xương khớp gói riêng. Đó là một môi trường đặc biệt, giúp cho tế 